\title{
Practices in Institutionalizing GIS for Revenue Mobilization: The Case of Secondary Cities in Tanzania
}

\author{
Ally Namangaya \\ Ardhi University, Dar es Salaam, Tanzania \\ Email: namangaya@yahoo.com
}

How to cite this paper: Namangaya, A. (2018). Practices in Institutionalizing GIS for Revenue Mobilization: The Case of Secondary Cities in Tanzania. Current Urban Studies, 6, 559-572.

https://doi.org/10.4236/cus.2018.64030

Received: September 13, 2018 Accepted: December 24, 2018

Published: December 27, 2018

Copyright $\odot 2018$ by author and Scientific Research Publishing Inc. This work is licensed under the Creative Commons Attribution International License (CC BY 4.0).

http://creativecommons.org/licenses/by/4.0/

\begin{abstract}
Increasingly Geographical Information System (GIS) has been seen as an important infrastructure component for revenue enhancement and urban development management as used for property identification, verification, taxation and spatial development governance. The paper is an attempt to learn from the experiences of developing GIS in Tanzania, which has also taken place in many other Sub-Saharan countries, for the purpose of boosting revenue collection and enhance land governance functions. The paper was developed through the review of the policy and program evaluation documents, discussions in the respective cities, authors' support to established alternative GIS architecture in some cities and evaluations of the same at later stages. Some of the major findings from the study were that although a lot of donor and government resources had been invested in the hardware and short terms training as well as consultants on GIS, there were no comprehensive programmes that ensured coherent capacities and targets on the GIS development. As a result, the GIS has never been fully institutionalized in the business processes of the municipal authorities. Relevantly, system architectures were non-conformable with the legal mandates of some crucial spatial data custodians in cities. Failure to spread GIS and to have proper system architecture is also attributed by a single focus nature of the systems developed, either property tax or revenue or land use planning while ignoring other needs and stakeholders who would contribute in sustaining the systems.
\end{abstract}

\section{Keywords}

Geographical Information System (GIS), Revenue Collection, Property Taxes, Tanzania 


\section{Introduction}

Tanzania, like many other Sub-Saharan countries, for over three decades, has been attempting to establish GIS databases to boost revenue collection for the better financing of urban infrastructure and governance functions. However, the road in this development process has been bumpy and the success level is debatable. This paper is an attempt to trace the GIS databases development for municipal financing in Tanzania in order to inform on what the major challenges have been and how world-wide experiences could shed light on the possible strategies for improving the outcomes of GIS databases establishments.

Despite the significant economic growth, Africa as a developing region, still experiences massive urban poverty and other social problems that hinder the investment into infrastructure, keeping the region burdened with high service deficits and shortages in access to technologies (UN-Habitat, 2014; Oyedele, 2012). For instance, in Tanzania, Mainland Poverty Assessment (2015) showed that almost four out of ten people live in below international poverty line of two United States dollars a day. Although the importance of investing in urban infrastructure to stimulate economic growth is widely acknowledged (Ingram \& Brandt, 2013; Ingram \& Flint, 2011), the question that remains is: how to obtain these resources and from where? Consequently, it becomes necessary to discuss the strategies that can effectively mobilize better municipal finances. Authors such as Connolly et al. (2003) and Peterson (2008) discuss how land asset management, constitutes a broad arena for municipal policies to finance urban areas, and how locational based taxes have been used widely as a source of land value capture and mobilization of resources to finance infrastructure provisions in urban areas. For instance, a widely known tax is the property tax, which is charged on a property, which can be land or a physical building (De Cesare, 2002; Smolka \& Iracheta, 1999). Property tax charged on land and not a building is called the land rent. Connolly and Bell (2011) consider property taxes as the most important source of local revenues, which is seen to be fair, efficient, simple to administer and promotes accountability by linking taxes paid with services provided. It is this hope of simplicity that had attracted many governments in developing countries to try to strategies on how to efficiently collect this type of tax.

One way that has been used by many countries to try to increase efficiency in the land-based taxing system is the development of computerized spatial data systems or commonly called Geographical Information System (GIS) for the particular urban area. Many countries including Denmark, Brazil and Australia that have successfully established spatial data systems had their entrance point on property identification for property tax collections (Enemark et al., 2005). This brings foundation and justification for the investment required to produce the data, hardware and technical staff required for the computerized spatial data system. 
Tracing further the development of computerized spatial data system in many countries it becomes evident that those who continued to use their computerized spatial data systems only for revenue goals soon had their systems collapsed or made irrelevant, but those who expanded the role of their GIS into other portfolios especially on process aspects such as land and spatial development governance and overall service provisions managed to sustain their system for a longer time (Davis \& Fonseca, 2006; Rajabifard et al., 2002).

Expansion of the GIS applications in many countries has been observed to be fostered by having collaborative agreements among parties that use or can use GIS, including government collection sections, urban land administration and management sections and utility service providers. These agreements tend to include the primary purpose of GIS, in which land administration and management have frequently been the initial area of expansion the system portfolio. Integrating GIS database for property data with land administration facilitates the use of common address systems where the practice has always been to link the unique parcel or parcel identifier number with the customer identifier numbers (Jacoby et al., 2002).

The other common forms of agreements on GIS database institutionalization have been on roles and mandates within urban authority's departments and sections. In this regard, there lacks a standard practices in some issues such as administrative locations of databases. The usual practice on this issue has been to locate GIS database either in departments dealing with information technology, urban planning, and engineering or as a fully fledged GIS department (ibid). It is a common practice that updating and operational responsibilities are administered by units separated from the supervising or coordinating entities. There are even innovative cases especially in North America and Australia where updating and maintenance have been commissioned to the private sector (Rajabifard et al., 2006; McLaughlin \& Nichols, 1994).

The other form of innovations has been to have direct cost recovery strategies inbuilt in the system institutionalization. This has been made possible first by creating platforms for data use and visualization whose consumers are beyond the traditional revenue departments (Masser et al., 2008; Crompvoets et al., 2004). The "paying" users include utility agencies who would buy a license to use the data, the general public, private land developers and planners as well as investors, where copies of hardcopy or digital data are made available at cost (Dessers et al., 2011).

\section{Study Context and Sources of Information}

The data compiled for this paper was a result of several protracted engagements of the author with councils and the ministry responsible for local government by then it was Prime Minister's Office, Regional Administration and Local Government, PMO-RALG. Currently the office has been moved to the President's office, (President Office, Regional Administration and Local Govern- 
ment-PORALG). Therefore conceptually the methodology was a participant observer. The engagement was on three projects, the first being the evaluation of urban development projects towards the preparation of Tanzania State of Cities Report in 2011-2013 where the author was resource person contracted by Tanzania Cities Network.

The cities involved are Zanzibar municipality and five cities of Arusha, Mbeya, Mwanza, Tanga and Dar es Salaam (which contained municipalities of Temeke, Kinondoni and Ilala). The second engagement was giving technical support in GIS and urban planning for cities in Urban Local Government Support Programme in 2013-2014, whose target was the eighteen third-tier cities. The third engagement was in the preparation of GIS Strategy for Cities in Tanzania Strategic Cities Project (TSCP). During the undertaking of projects, interviews were held with local government officials and donor organization as well as a review of documents such as project evaluations reports. There were also meetings and feedback sessions in all projects. Revenue data for the consecutive three years were obtained from the PO-RALG website, where dashboard is available showing local government own source revenue collection for every year. The data is organised by regions and council starting from 2014/15 (Figure $1)$.

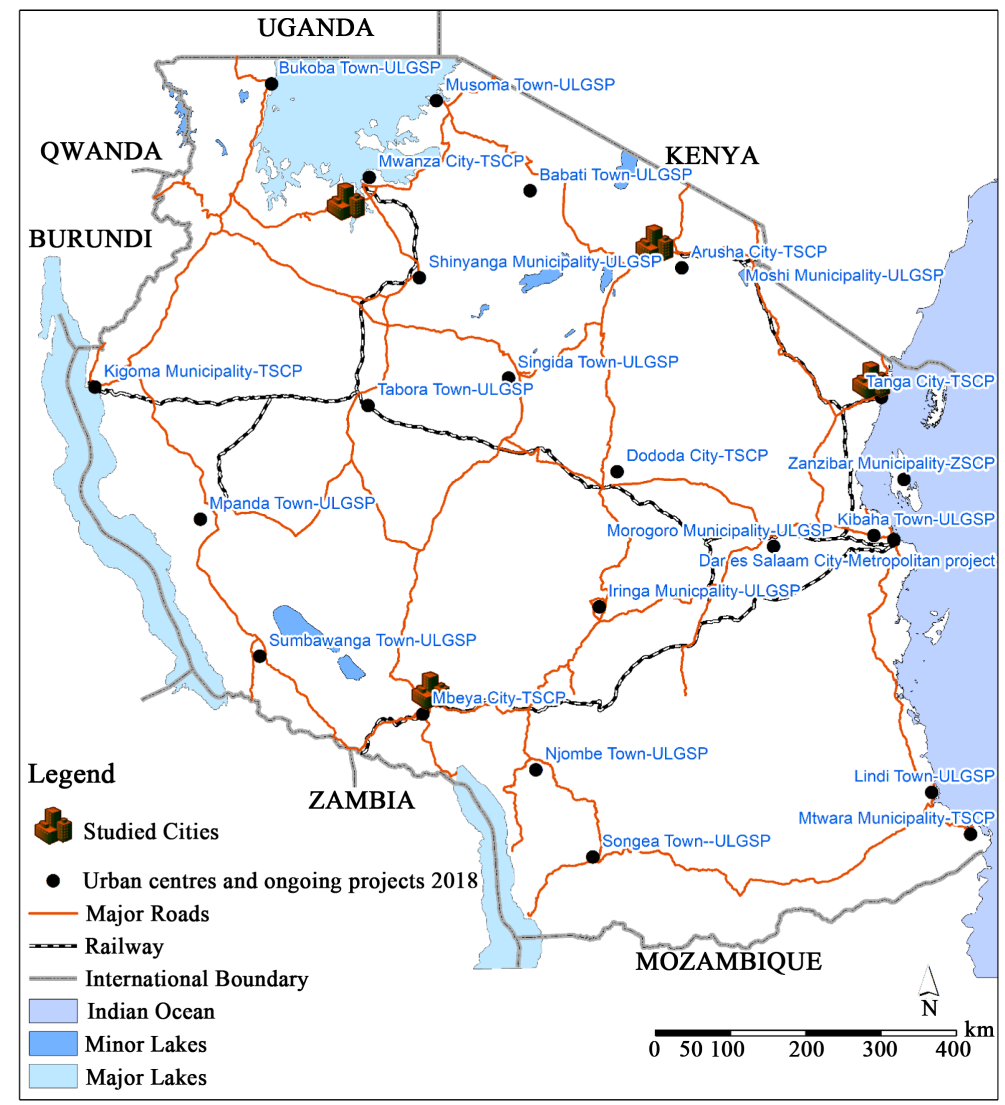

Figure 1. Tanzania urban centers and the studied cities. Source: Author preparation using open data sources. 


\section{Evolution of Application of GIS in Tanzania}

The history of the development of GIS in Tanzania shows that the earliest systematic institutionalization of GIS for urban development started in 1990-1992 when UN-HABITAT came to support a review of the Dar-es-Salaam Master Plan. The times were characterized by a paradigm shift in urban planning approaches as it was perceived that the binding urban land use master plans were too rigid and their preparation process was not inclusive, technocratically driven and less sensitive to environmental concerns (Halla, 2007; Namangaya, 2013; Kasala, 2015). UN-HABITAT introduced the system of Environmental Planning and Management (EPM), whose central component was to integrate Environmental Management Information System (EMIS), which could enable flexibility in land use evaluations and decisions making according to stakeholders concerns and environmental sensitivity.

The GIS databases development involved digitization of images and hardcopy maps such as topographic sheet $(1: 50,000)$ and machine plots $(1: 2500)$ which provide altitude data in the form of contours and spot heights; building locations; landscapes level land cover data with generalized granularity and cadastral data. Most of these datasets were of vector format. The task was primarily for urban plans and therefore the Ministry of Lands, Housing and Human Settlements Development (MLHHSD), some sector ministries and the Dar-es-Salaam City Council were the main actors. The key software used was Map Info, Arc-Info and ArcView.

The process enabled some advancement in the establishment of EMIS in Dar es Salaam City and introduced the use and appetite of GIS databases in the government. However, in its operations, the system was isolated, not linked to other systems. Although its use was supposed to facilitate continuous spatial decision-making processes, its application was much limited to plan production. This phenomenon could be attributed to its failure to integrate business processes of the city council, even with the urban planning departments. The evaluation reports pinned the underperformance of EMIS on poor ownership of the project by local authorities and incapacity of local staff and administrative systems to absolve the technology (Tanzania Cities Network, 2012).

While the development of EMIS in Dar es Salaam was continuing, a parallel initiative was taking shape in Dar es Salaam from 1993 to 1999 under the World Bank and NORAD (Norwegian Development Agency) in the project called Urban Sector Engineering Project (USEP). The project target was to enhance properly tax collection initially in Dar es Salaam. Its GIS was principally about the use of the aerial photography to capture buildings and develop spatial buildings databases which are linked to valuation rolls. The project was later expanded under the new initiative as an Urban Sector Rehabilitation Project (USRP) to include other secondary urban centers which are Arusha, Iringa, Mbeya, Moshi, Morogoro, Mwanza, Tabora and Tanga. Although in original design the USRP did not have a revenue component, the capacity building interventions across urban de- 
velopment stakeholders including utility agencies matched with the need to finance more infrastructures in urban areas resulted in the efforts to collect more revenues through the establishment of datasets (McCluskey \& Franzsen, 2005). The fact that the project focused on the strategic area of revenue collection, its attempt to have a specialized database was well received. This facilitated the establishment of self-operated GIS databases and valuation rolls in Temeke and Kinondoni Municipal Councils. There were several partial systems where local programmers managed to use proprietary software to create computerized revenue collection systems. The GIS database for revenue and urban development continued to be used in an ad hoc manner where each city crafted own solutions until around 2015 when a local company, Dayone Softcom Technologies (T) Limited, developed a software known as Municipal Revenue Collection Manager (MRECOM). MRECOM has been in use by over 16 local authorities, where the development is more of tax payment and management systems rather than GIS database for properties and businesses.

Taking the hindsight, it is evident that despite the indication of ownership of GIS system and mainstreaming of the same in the respective councils shown by the fact that the councils funded GIS operations from internal revenues, the systems remained as a departmental affair, mainly limited to departments dealing with lands administration/planning and revenue mobilization. Moreover, the data system of internal revenue sections and those on by the departments dealing with land matters (buildings and plots) were not linked, leading to revenue leakages and untapped revenue sources. There were also serious gaps in the data with many houses left out and inaccurate valuation data (McCluskey \& Franzsen, 2005). Worth noting that when USEP was being very successful, Tanzania Revenue Authority (TRA) had attempted to take over the responsibility of collecting property tax, however they soon faced the challenges of accuracy of location and valuation data and updating the database, thus returned the system to be managed by local authorities.

From 1997 to 2002 UNHABITAT pulled other agencies including DANIDA (Danish Development Agency) and SIDA (Swedish Development Agency) to replicate the process of preparation and components of Dar es Salaam Urban strategic plans framework, including the establishment of EMIS approaches in secondary cities of Mwanza, Iringa, Moshi, Mbeya and Tanga. Therefore GIS database similar to that of Dar es Salaam was established in these cities. The application of high-resolution imagery was enhanced through the use of aerial photographs and provision of well-equipped GIS rooms. In these GIS rooms multiple layers of spatial data, mostly those which were archived previously in hardcopy and newly collected urban land use data. In the replicated EMIS setup there was a better attempt to some extent aligned the data to the demand of the Ministry responsible for lands (MLHHSD), however, the system generally remained isolated from other business processes of the councils and continued to exclude land ownership data it the database structure. Land ownership data 
would have linked the councils' buildings data and the MLHHSD cadaster data used for charging land rent. In the early 2002, when the MLHHSD refused to approve the Dar es Salaam Urban strategic Planning Framework it was perceived by some donors who financed the process as a stumbling block to the whole process. Interviews with some respondents indicate that this perception coupled with the expanded portfolio of Ministry responsible for local government (Prime Minister's Office, Regional Administration and Local Government, PMO-RALG) led to the shifting of host ministry in donor financing of local governments to the PMO-RALG. PMO-RALG then started to get involved in GIS development.

From 2007, DANIDA started financing the government of Tanzania through PMO-RALG; whose one of the programmes was Urban Development and Environmental Management (UDEM) Framework. The program replicated the architecture of GIS database similar to the one under sustainable cities programme, in the form of EMIS, and rebranded it as UEMIS (Urban Environmental Management Information System).

UDEM involved all councils even those in rural areas where the focus was in small towns and trading centers. Due to the nature of the rural contexts, districts environment and natural resources data were more integrated into the framework and the focus was towards a wider sustainable development. Generally, the success was mainly on retooling and some establishment of GIS units. However, the same challenges of isolating GIS from councils' wider business processes, and staff incapacity (despite multiple training sessions) contributed to the demise of UDEM.

After the abolishment of development levy in 2004-2005 which was charged on individual citizens in the locality, most local authorities experienced serious lack of resources. Then the projects funded by different donors came in to support local revenue mobilization in some secondary cities such as Arusha, Tanga and Mwanza. For instance in Arusha City, the council benefited from Deutscher Entwicklungsdienst (German Development Service, DED) experiment, which successfully introduced local tax reform that saw a tremendous increase in capacity to capture a wide range of own source revenue including service levy. The service level is charged at a rate of zero point three percent of values of goods and services produced by each firm in the city. Also, the use of computers was introduced and mainstreamed in tax issues. Performance in each city was different and no standardization of systems and procedures was sought for all cities.

In 2010, Tanzania received financing from the World Bank on Strategic Cities Project (TSCP). The project focused on capacity building of councils in the provision of services in the seven secondary cities in the country, namely Mwanza, Tanga, Arusha, Mtwara, Dodoma, Mbeya and Kigoma. While component one focused on physical infrastructure development, component two of the project involved capacity building and one of its subcomponents was the enhancement of revenue collection. The GIS database development was a key element in the 
implementation of the subcomponent as its role was to link property data and valuation rolls with revenue management system developed known as local Government Review Collection Information System (LGRCIS). Other data in the system included the description of owners of some registered businesses, billboards and similar data that had a potential of tax revenues.

Data for populating GIS database were collected through ground picking of buildings data, whose enumerator were guided by the high-resolution satellite imagery. Attribute data on the properties were collected and assembled in $\mathrm{Mi}$ crosoft Access files. GIS database was supposed to link with LGRCIS using a server and network that was also connected to servers in PMO-RALG head office.

GIS database was comprised of building footprint as polygons, with attribute data describing, height, use, materials, utility connections and photographs of structures. These data were compiled in the form that was envisaged to enable the system to undertake derivation of property values using algorithms that use the information in the database. The process of generating values and therefore tax rates for properties using an algorithm that is based on the information in the database is called mass valuation. Supposedly, the mass-valuation procedure would speed the process of generating taxable rates.

Data collection exercise for the GIS databases lo link with LGRCIS was done between 2010 and 2011 and all participating councils received processed data and equipped GIS room by 2013. To date in all the cities, there has only been a success in institutions LGRCIS in councils' revenue sections while the backend GIS database has remained in the hands of town planners and land surveyors, without linking to the LGRCIS.

\section{A Comparative Analysis of the GIS Data Structures}

A comparative assessment of the data type as prescribed in Table 1 and Figure 2 shows that the GIS database in EMIS and UEMIS are substantially different from that under MRECOM and LGRCIS. The former focused on internal urban management functions while the latter focuses on revenue collection per se. All of them are unconnected to non-land functions of the councils and external functions of service providers like utility agencies. None of the GIS databases managed to be server based (web-enabled) despite the fact that LGRCIS and MRECOM were designed to be like that.

The resolution of the data in EMIS and UMIS was rather coarse, hence unable to show properties or buildings although they contained sets of data with utility lines. The resolution of the GIS database for LGRCIS was detailed enough to show buildings but did not contain data on utilities or even social facilities. None of the spatial datasets contained property cadaster data (plot boundaries) which is the major omission in terms of a potential multiplicity of use of data that would greatly contribute to the continued relevance of the datasets beyond one particular project. 


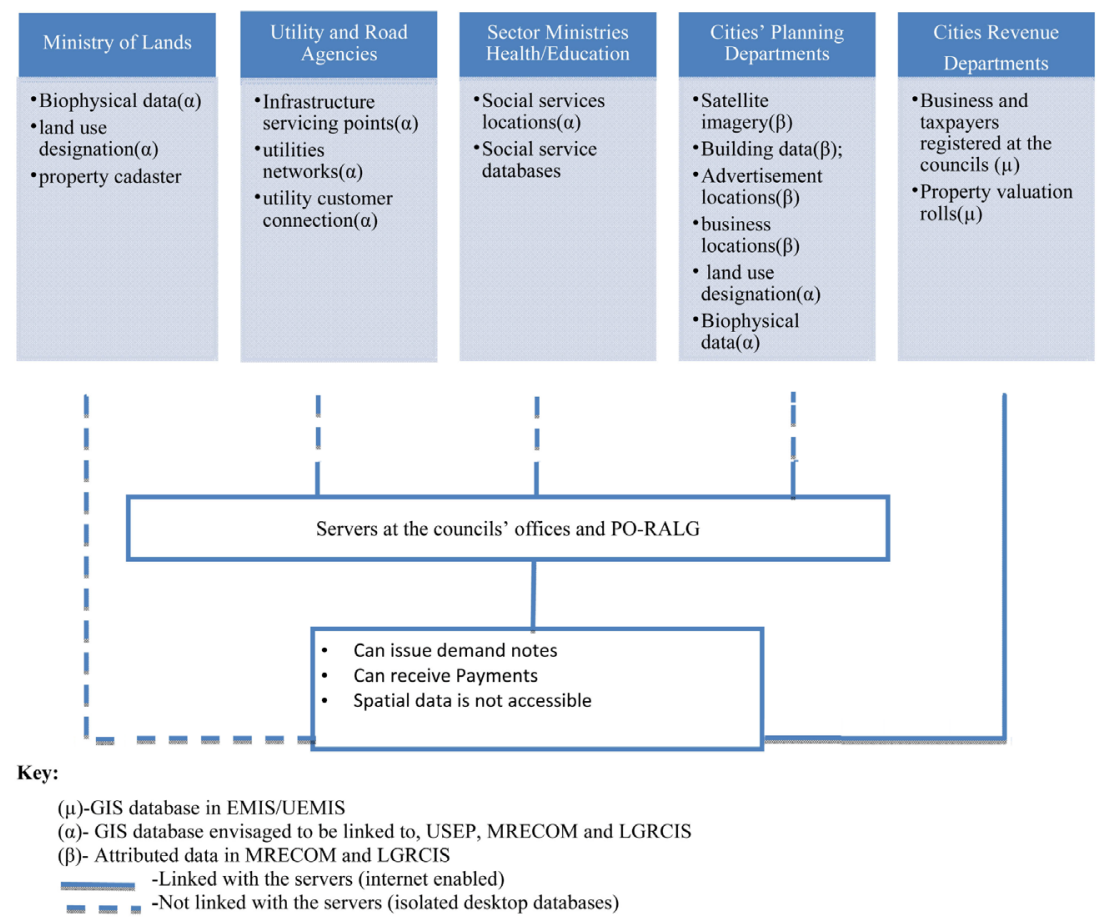

Figure 2. Data structures in GIS databases that have been used in the urban local governments. Source: Author's representations.

Table 1. Comparison of the GIS database systems using considerations established in literature review.

\begin{tabular}{|c|c|c|c|c|c|c|}
\hline $\begin{array}{l}\text { Computerized spatial } \\
\text { database system }\end{array}$ & $\begin{array}{l}\text { Year } \\
\text { in use }\end{array}$ & $\begin{array}{l}\text { Integration of } \\
\text { revenue } \\
\text { and business }\end{array}$ & $\begin{array}{l}\text { Integrate wider } \\
\text { business process of } \\
\text { the local authority }\end{array}$ & $\begin{array}{l}\text { Facilitating urban } \\
\text { development } \\
\text { management and } \\
\text { decision making }\end{array}$ & $\begin{array}{c}\text { Server } \\
\text { connectivity } \\
\text { and multiple } \\
\text { platforms/gadgets }\end{array}$ & $\begin{array}{c}\text { Link } \\
\text { data with } \\
\text { MLHHSD and } \\
\text { utility agencies }\end{array}$ \\
\hline $\begin{array}{c}\text { Environment Management } \\
\text { Information System (EMIS) } \\
\text { in Dar es Salaam }\end{array}$ & $1990-2000$ & $x$ & 0 & 0 & $x$ & 0 \\
\hline $\begin{array}{l}\text { Urban Sector Engineering Project } \\
\text { (USEP-GIS) in Dar es Salaam }\end{array}$ & 1990-1996 & 0 & O & O & $x$ & $x$ \\
\hline $\begin{array}{l}\text { Urban Sector Rehabilitation Project } \\
\text { (USRP-GIS) in secondary cities }\end{array}$ & $1995-2004$ & $\mathrm{x}$ & 0 & 0 & $x$ & 0 \\
\hline $\begin{array}{l}\text { Environment Management } \\
\text { Information System (EMIS) } \\
\text { in Secondary cities }\end{array}$ & $2000-2006$ & $\mathrm{x}$ & O & 0 & $x$ & 0 \\
\hline $\begin{array}{l}\text { Urban Environment Management } \\
\text { Information System (UEMIS) in } \\
\text { tertiary cities and small towns }\end{array}$ & $2007-2010$ & $x$ & 0 & 0 & $\mathrm{x}$ & $\mathrm{x}$ \\
\hline $\begin{array}{l}\text { Capacity building for city } \\
\text { financing in secondary cities }\end{array}$ & 2004-2010 & 0 & 0 & $\mathrm{x}$ & $\mathrm{x}$ & $x$ \\
\hline $\begin{array}{c}\text { Municipal Revenue collection } \\
\text { manager MRECOM in } 16 \text { councils }\end{array}$ & 2015-2014 & 0 & $x$ & $\mathrm{x}$ & 0 & $x$ \\
\hline $\begin{array}{c}\text { GIS to link with LGRCIS in } \\
\text { Secondary cities, Regional Cities and } \\
\text { shifting the operations to the TRA }\end{array}$ & 2010-to date & 0 & $\mathrm{x}$ & O & O & $x$ \\
\hline
\end{tabular}

Source: Author's analysis. Falls squarely in the scope; $\bigcirc$ Falls squarely on the scope; $\times$-Not in the scope. 


\section{The Impact of the Current System on the Revenue Mobilization}

Examination of the impact of the LGRCIS on revenue collection for the past three years in the four studied secondary cities show that cities revenue collection jumped from a couple of hundred million to multiple billions from the year 2016/17 when the cities started using LGRCIS consistently (Table 2). There is

Table 2. Revenue collections trends in the studied cities (values in millions of Tanzanian Shillings).

\begin{tabular}{|c|c|c|c|c|c|c|c|c|c|c|c|c|}
\hline \multirow{4}{*}{ Year } & \multicolumn{3}{|c|}{ Arusha } & \multicolumn{3}{|c|}{ Mbeya } & \multicolumn{3}{|c|}{ Mwanza } & \multicolumn{3}{|c|}{ Tanga } \\
\hline & 2015 & 2016 & 2017 & 2015 & 2016 & 2017 & 2015 & 2016 & 2017 & 2015 & 2016 & 2017 \\
\hline & - & - & - & - & - & - & - & - & - & - & - & - \\
\hline & 2016 & 2017 & 2018 & 2016 & 2017 & 2018 & 2016 & 2017 & 2018 & 2016 & 2017 & 2018 \\
\hline $\begin{array}{c}\text { Total own } \\
\text { source revenue }\end{array}$ & 33.7 & $11,021.9$ & 7881.8 & 4.4 & 4642.7 & 3667.9 & 7.4 & $10,839.0$ & $16,296.5$ & 50.4 & 6805.6 & 7046.4 \\
\hline $\begin{array}{l}\text { Revenue from } \\
\text { Property taxes }\end{array}$ & 7.5 & 417.9 & 2.9 & 0 & 44.6 & 0 & 0 & 19.1 & 4.7 & 30.0 & 42.7 & 1.2 \\
\hline $\begin{array}{l}\text { percentage of property } \\
\text { tax to total tax }\end{array}$ & $22.20 \%$ & $3.79 \%$ & $0.04 \%$ & & $1 \%$ & & & $0.18 \%$ & $0.03 \%$ & $60 \%$ & $1 \%$ & $0.02 \%$ \\
\hline $\begin{array}{c}\text { Total number of } \\
\text { houses in database } 2012\end{array}$ & 102,872 & & & 100,298 & & & 81,588 & & & 53,996 & & \\
\hline Houses in database & 23,445 & & & 38,745 & & & 60,018 & & & 22,124 & & \\
\hline $\begin{array}{c}\text { Percentage of } \\
\text { houses in database }\end{array}$ & 23 & & & 39 & & & 73.56 & & & 40.97 & & \\
\hline \multicolumn{13}{|c|}{ Revenue from location-based taxes } \\
\hline Guest house levy & 0.03 & 59.3 & 46.2 & & 99.6 & $120, .4$ & 0.04 & 357.8 & 391.7 & & 59.0 & 80.8 \\
\hline $\begin{array}{l}\text { Other business } \\
\text { license fees }\end{array}$ & 8.2 & 1301.7 & 1504.2 & 4280.0 & 730.2 & 794.3 & 1.7 & 2069.7 & 2143.0 & 2.8 & 576.1 & 582.4 \\
\hline $\begin{array}{l}\text { Other levies on } \\
\text { business activity }\end{array}$ & 2.3 & 736.1 & 127.1 & & 114.6 & 144.2 & & 150.6 & 21.5 & 8.4 & 112.2 & 22.6 \\
\hline $\begin{array}{l}\text { Intoxicating } \\
\text { liquor license fee }\end{array}$ & 0.2 & 46.8 & 56.4 & 0.08 & 42.4 & 43.6 & 0.08 & 71.9 & 88.3 & & 22.2 & 31.6 \\
\hline $\begin{array}{c}\text { Permit fees } \\
\text { for billboards, } \\
\text { posters or hoarding }\end{array}$ & 0.7 & 815.3 & 4.1 & & 538.3 & 38.7 & & 937.8 & 260.2 & & 1.3 & 2.2 \\
\hline Advertising fee & & 118.5 & 19.2 & & & & & & & & & \\
\hline Service levy & 0.6 & 3437.5 & 3633.4 & & 1384.2 & 1120.3 & 5.6 & 3816.8 & 4340.8 & 9.2 & 1549.8 & 1948.0 \\
\hline Land Rent & & & & & 2.6 & & & 235.8 & 0.02 & & & \\
\hline $\begin{array}{l}\text { Land survey } \\
\text { service fee }\end{array}$ & & & & & 3.9 & 9.9 & & & & & 2652.9 & 3019.8 \\
\hline $\begin{array}{l}\text { Total revenue from } \\
\text { location based taxes }\end{array}$ & 19.6 & 7870.4 & 5557.3 & 4.4 & 3061.1 & 2322.1 & 7.4 & 7929.1 & 7276.5 & 50.4 & 5016.3 & 5688.6 \\
\hline $\begin{array}{l}\text { Percentage of location } \\
\text { based to total taxes }\end{array}$ & 58 & 71 & 71 & 100 & 66 & 63 & 99 & 73 & 45 & 40 & 73 & 81 \\
\hline
\end{tabular}


are huge proportional contributions of locations based revenue sources, that is, those revenues sources where it is possible to know precise location and therefore facilitate the easy of collection, as listed in Table 2. This confirms the importance of locational database. Unfortunately, non-functionality of these databases means the precise information of the sources are unknown and the physical follow-up are only undertaken to those premises that are physically known by individual revenue staff or have opted to come and register themselves. In a context of informal development, it is certain that many businesses are missed.

Property tax despite being heralded as a crucial source of revenue, its contribution to the council own source revenue in very small. For instance, for the peak year of revenue collection which is 2016/17. It was 3.8\% in Arusha, under $1 \%$ in Mbeya, $17.6 \%$ in Mwanza and again under 1\% in Tanga. Stating it differently, the expensive investment in digitizing buildings and collection building data for the TSCP cities had a very marginal return.

One reason used to explain this paradox is the low proportion of houses that are in the tax register. The promotion of properties in the database per city was; Arusha (22.8\%), Mbeya (38.6\%), Mwanza (58.3\%), and Tanga (40.97\%). If all these houses were in the databases, the revenue councils would have increased in multiples.

Available explanations for the low performances of GIS database for property data is that when the system of LGRCIS was developed it assumed mass valuation of properties, hence, the detailed collection of attribute data of buildings to enable algorithms in LGRCIS to compute values of buildings and set tax rates. Accordingly, the form of Unique Parcel (object) Identifier Number (UPIN) used for objects was Building Reference Number (BRN). As a plot could have more than one building, hence multiple BRN exist. This structure has the advantage of enabling utilizing BRN also to easily capture multiple businesses in a plot, e.g. different business licenses are linked to different BRN. However, legally valuation rolls as per Urban Authorities (Rating) Act, 1983, Law No. 2 of 1983 requires values for the rating to be done by a registered valuer and approved by the Chief Valuer, hence mass valuation is not legally sanctioned. Moreover, valuation is based on a property or plot (cadastral) boundary, thus even if several buildings exist in a plot they are identified as a single property. Therefore in the valuation rolls, the UPIN is based on property identification number (PRN). Incidentally, property boundary is also used by the ministry of land to charge land rent and is also the unit used for land use planning and development control. The councils are supposed to get $30 \%$ revenue collected from land rent in the areas of their jurisdiction. The result of this mismatch in the UPIN was a failure to link valuation rolls (ratings) that was done for each building in the city with the buildings' data in the GIS database that was supposed to be the backend connection to LGRCIS system. Therefore LGRCIS could neither use mass valuations nor GIS database.

A point could be made of Arusha City where through the innovation of the 
revenue department which enabled them to collect more in 2003/14 when they decided to print maps from GIS database and use them to physically locate houses and inquire the status of payments of taxes. This was the a cumbersome procedure and could not be sustained, as shown in Table 1, where they decided to focus on service levy, mainly because of good experience they had acquired from the Deutscher Entwicklungsdienst. Other city councils failed to find the reasonable use of developed GIS database ever since, five years from when they started to use LGRCIS.

Despite the challenges in developing functional GIS database to link with LGRCIS, the same model was replicated eighteen tertiary cities in the programme known as Urban Local Government Support Programme (ULGSP) under the additional loan agreement from the World Bank. The situation in tertiary cities has been more challenging as in addition to the faulty GIS-LGRCIS link model, there are serious capacity challenges in terms of skills and financial resources. Many of these tertiary cities, for instance, Bariadi Town Council has not been able to establish GIS database, the GIS room does not have a network or physical connection to the server, and property valuation was done without the use of maps or location data such that even when GIS is developed it cannot be linked to the building or property unique identifier. Faced with these contradictions, the central government has opted to move property tax collection from the city authorities to a central government agency, Tanzania Revenue Authority (TRA). TRA in most of the cities has ignored the rating in the valuation rolls and focuses on charging minimal flat rates for the property owners who will themselves come forward to pay taxes, as there is no reliable database to trace all properties. With the property tax moved out of local authorities, the possibility of linking LGRCIS with GIS database is becoming narrower, and the same problems of unconnected and un-updated building database are bound to continue.

\section{Conclusion}

Since 1990s, Tanzania cities have attempted to establish and to spread GIS in their business processes. The earlier attempts focused on planning and land use with data granularity too coarse to facilitate meaningful urban development monitoring (development control) or revenue collection.

The challenge of data granularity and relevance of UPIN also affects the recent attempt by TSCP and ULGSP as the reference to the buildings is in contradiction with the laws of the land which require reference to plots. The overarching explanation is that the focus of database in local government has never been to develop complete datasets for urban functionality but to have single purpose GIS database that responds to the purpose of a loan or grant.

This lack of integration of the GIS databases with wider business processes and the needs of the cities denies the councils to design a data structure that would capture other revenue sources, such as payment for solid waste or link payment for water and power with property data. Such linkages would be 
enabled by a working internet and server networks shared among councils departments and utility service providers.

To conclude, the future of GIS requires first to examine the entire business process of urban councils and create an appropriate data structure that could support a functional set of city business processes, reflect required granularity of data, connectivity and interoperability. The recent decision by the PO-RALG to migrate to open source software, QGIS, if it will be actualized, will likely fasten more integration of database and sharing of data among departments and agencies in the cities. This is because the use of open source software will enable every user of spatial data to have similar sets of data and to add data accordingly, and thus facilitate the process of populating the GIS databases. The current use of proprietary software limits data exchanges within the councils and with other agencies.

\section{Conflicts of Interest}

The author declares no conflicts of interest regarding the publication of this paper.

\section{References}

Connolly, K., \& Bell, M. (2011). Strengthening the Local Property Tax: the Need for a Property Tax Expenditure Budget. Lincoln Institute for Land Policy Working Paper.

Connolly, P., Goldsmith, W., \& Mabin, A. (2003). Urban Responses to the "Lost Decades". Land Lines, 15, No. 2.

Crompvoets, J., Rajabifard, A., Bregt, A., \& Williamson, I. (2004). Assessing the Worldwide Developments of National Spatial Data Clearinghouses. International Journal of Geographical Information Science, 18, 665-689. https://doi.org/10.1080/13658810410001702030

Davis, C., \& Fonseca, F. (2006). Considerations from the Development of a Local Spatial Data Infrastructure. Information Technology for Development, 12, 273-290. https://doi.org/10.1002/itdj.20048

De Cesare, C. (2002). Toward More Effective Property Tax Systems in Latin America. Land Lines, 14, No. 1.

Dessers, E., Van Hootegem, G., Crompvoets, J., \& Hendriks, P. H. (2011). Integrating Spatial Information and Business Processes: The Role of Organizational Structures: Spatial Data Infrastructures in Context of North and South.

Enemark, S., Williamson, P., \& Wallace, J. (2005). Building Modern Land Administration Systems in Developed Economies. Spatial Science, 50, No. 2.

Halla, F. (2007). A SWOT Analysis of Strategic Urban Development Planning: The Case of Dar es Salaam. Habitat International, 31, 130-142.

Ingram, G., \& Brandt, L. (2013). Global Infrastructure Global Infrastructure: Ongoing Realities and Emerging Challenges: In Infrastructure and Land Policy (pp. 3-20). Cambridge, US: Lincoln Institute of Land Policy.

Ingram, G. K., \& Flint, A. (20110. Cities and Infrastructure: A Rough Road Ahead. Land Lines, Lincoln Institute of Land Policy.

Jacoby, S., Smith, J., Ting, L., \& Williamson, I. (2002). Developing a Common Spatial Da- 
ta Infrastructure between state and Local Government-An Australian Case Study. International Journal of Geographical Information Science, 16, 305-322. https://doi.org/10.1080/13658810110096001

Kasala, S. E. (2015). A Return to Master Planning: A Misconception of the Theory of Paradigm Shift? Global Journal of Human-Social Science Research, 15, No. 2.

Masser, I., Rajabifard, A., \& Williamson, I. (2008). Spatially Enabling Governments through SDI Implementation. International Journal of Geographical Information Science, 22, 5-20. https://doi.org/10.1080/13658810601177751

McCluskey, W. J., \& Franzsen, R. (2005). An Evaluation of the Property Tax in Tanzania: An Untapped Fiscal Resource or Administrative Headache? Property Management, 23, 43-69. https://doi.org/10.1108/02637470510580589

Mclaughlin, J., \& Nichols, S. (1994). Developing National Spatial Data Infrastructure. Journal of Surveys and Engineering, 120, 62-76. https://doi.org/10.1061/(ASCE)0733-9453(1994)120:2(62)

Namangaya, A. (2013). A Comparative Assessment of the Merits of Master Plans versus Strategic Urban Development Plans in Guiding Land Use Development. Journal of Building and Land Development, 21-37.

Oyedele, A. (2012). The Challenges of Infrastructure Development in Democratic Governance. Conference Paper, FIG Working Week 2012.

Peterson, G. E. (2008). Unlocking Land Values to Finance Urban Infrastructure. The World Bank. https://doi.org/10.1596/978-0-8213-7709-3

Rajabifard, A., Feeney, M., \& Williamson, P. (2002). Future Directions for SDI Development. International Journal of Applied Earth Observation and Geoinformation, 4, 11-22. https://doi.org/10.1016/S0303-2434(02)00002-8

Rajabifard, A., Masser, I., Binnsa, A., \& Williamson, I. (2006). The Role of Sub-National Government and the Private Sector in Future Spatial Data Infrastructures. International Journal of Geographical Information Science, 20, 727-741. https://doi.org/10.1080/13658810500432224

Smolka, M., \& Iracheta, A. (1999). Mobilizing Land Value Increments to Provide Serviced Land for the Poor. Land Lines, 11, 14.

Tanzania Cities Network (2012). Tanzania State of Cities Report. An Unpublished Government Report.

UN Habitat (2014). The State of African Cities 2014. Re-Imagining Sustainable Urban Transitions, International Report, Nairobi. 